\title{
"Maybe I Should Try Out Becoming a Teacher": Why Science Majors Enter Science Teaching
}

\author{
Ashley N. Coon ${ }^{1}$
}

\author{
${ }^{1}$ University of Maryland, UNITED STATES \\ *Corresponding Author: acoon@umd.edu
}

Citation: Coon, A. N. (2020). "Maybe I should try out becoming a teacher": Why science majors enter science teaching. Interdisciplinary Journal of Environmental and Science Education, 16(2), e2213. https://doi.org/10.29333/ijese/7817

\begin{abstract}
ARTICLE INFO
ABSTRACT

Received:

9 January 2020

This multiple-case study was conducted to evaluate claims that the literature on the recruitment of science majors into science teaching is sparse and unable to adequately explain why undergraduates decide to pursue science teaching. I interviewed six undergraduate science majors who have committed to an initial

Accepted:

13 February 2020 science teacher preparation program to ascertain their motivations for choosing a career in teaching. This analysis reveals that the literature has not adequately identified all the reasons why a group of science majors decided to pursue science teaching. Four novel motives were identified which should inform future research into science teacher recruitment.
\end{abstract}

Keywords: teacher recruitment, science education, science teacher education, secondary science, career choice, teacher identity

\section{INTRODUCTION}

"Maybe I Should Try Out Becoming a Teacher": Why Science Majors Enter Science Teaching

Students, particularly those who attend public schools in low income, high minority areas, are increasingly likely to have out-of-field teachers for science (Cross, 2017; Kahle \& Kronebusch, 2003; Moin, Dorefield, \& Schunn, 2005; Sutcher, Darling-Hammond, \& Carver-Thomas, 2016). This shortage of in-field secondary science teachers is due in part to the inability of teacher preparation programs to recruit science majors into science teaching (Ingersoll \& May, 2012; Moin et al., 2005; Wilson, Bell, Galosy, \& Shouse, 2004). To increase the number of recruits into initial science teacher preparation programs, schools of education must have access to research that explicates successful strategies for identifying and recruiting science majors; however, research in this area is sparse (Allen, 2005; Luft, Wong, \& Semken, 2011). Still, a review of the literature related to the recruitment of science majors into science teaching does reveal insights into how career interest in science teaching forms, which factors contribute to the development of interest in science teaching, and what strategies are likely to be effective to recruit science majors into science teaching, although it also reveals that existing studies include primarily white, female participants and have relied almost exclusively on the use of surveys. In this multiple-case study, I use a content analysis approach to reveal the factors that motivated six diverse undergraduate science majors to enter a science teacher preparation program. These factors were compared to those identified in the literature on science teacher recruitment. This analysis reveals that the literature has not adequately identified the reasons why a group of science majors decided to pursue science teaching. These six science majors' decisions to enter teaching were motivated by four novel factors: the professions' alignment to their identities and values, the sense of community found in their college of education, a desire to enter the workforce quickly, and the negative example of prior teachers.

\section{LITERATURE REVIEW}

If the nationwide shortage of qualified secondary science teachers is to be reduced, schools of education must recruit more undergraduate science majors into science teacher preparation programs. To accomplish this goal, those administering science teacher preparation 
programs must have access to research that empirically demonstrates the best practices and policies for recruiting undergraduate science majors. Unfortunately, Luft et al. (2011) found that existing research on science teacher recruitment is sparse and generally limited to (a) reviews of existing, largely outdated, research on recruitment, (b) descriptions of existing science teacher recruitment programs, or (c) studies on teacher persistence. They concluded that:

If we consider recruitment to be the initial step in the science teacher education process, then there is a... great need for studies that follow the decision-making process of potential teachers, that explore how the recruitment process impacts one's experience in a preservice program (p. 472-3).

Nevertheless, existing literature does offer some insight into what factors are likely to impact potential recruits' interest in science teaching and how those factors can inform recruitment strategies to introduce science majors to science teacher preparation programs.

A wide range of factors motivates the decision to pursue secondary science teaching. Pre-service and in-service science teachers most frequently cite their affinity for science (Bull et al., 1994; Dawson, 2007; Dominguez et al., 2015; Eick, 2002; Espinet et al., 1992; Kilinç \& Seymen, 2014) and desire to make a positive social impact (Bull et al., 1994; Dawson, 2007; Dominguez et al., 2015; Eick, 2002; Kilinç \& Seymen, 2014) as the reasons why they entered the field of science education. Additional motivations for entering science teaching include a desire to work with youth (Bull et al., 1994; Dawson, 2007; Espinet et al., 1992; Kilinç \& Seymen, 2014, Westerlund et al., 2011), positive prior teaching experience (Dawson, 2007; Kilinç \& Seymen, 2014; Luft et al., 2005; Wang, 2004), positive impact by a former teacher (Dawson, 2007; Tomanek \& Cummings, 2000), valuing the teaching profession (Dawson, 2007; Dominguez et al., 2015; Espinet et al., 1992; Kilinç \& Seymen, 2014), and an opportunity to engage with science (Eick, 2002; Tomanek \& Cummings, 2000). Although not cited as a motivating factor in studies of U.S. pre- and in-service science teachers, studies of science teacher recruitment conducted internationally have also identified job conditions (such as salary, demand, and workload) as having a positive impact on students' decision to pursue science teaching (Dawson, 2007; Dominguez et al., 2015; Kilinç \& Seymen, 2014; Wang, 2004). Low teaching salaries, classroom management concerns (Evans, 1987; Worsham et al., 2013), discouragement from family and friends (Evans, 1987), and difficulty incorporating teacher preparation into their current plan of study (Worsham et al., 2013) have been identified as reasons why undergraduate science majors interested in science education do not become teachers. While some science majors consider a career in science education, but ultimately decide against becoming a teacher, most science majors will never explore this option. Specifically, high achieving science majors (as measured by GPA and science exam scores) are least likely to consider science teaching (Shugart \& Hounshell, 1995; Moin et al., 2005) as a career option.

A multitude of recruitment strategies, seeking either to identify science majors with nascent interest in science teaching or to inspire such interest in science majors who would never otherwise consider science teaching, have been recommended in the literature, although the efficacy of only a few have been evaluated. The most widely supported recruitment strategy is providing science majors with science teaching experience (Borgerding, 2015; Saxman et al., 2010; Schuster, 2013; Tomanek \& Cummings, 2000; Worsham et al., 2013). Financial incentives (in the form of stipends, scholarships, and tuition remission) are another widely utilized recruitment strategy. However, there is limited evidence for the effectiveness of this strategy, as Bull et al. (1994) and Liou et al. (2010) disagree over whether financial incentives draw previously uninterested science majors into science teaching. Hoff and Lee (1986) provide evidence that a course devoted to providing science majors with information about a career in science teaching is an effective recruitment strategy, although this study utilized a small sample and is outdated.

This multiple-case study was conducted to evaluate whether the literature on science teacher recruitment is sufficiently robust to encompass all the reasons for why a group of six undergraduate science majors decided to pursue science teaching. Specifically, I will answer the following question: What factors motivated six undergraduate science majors to enter a science teacher preparation program, and have all of these factors been described in the literature on science teacher recruitment? This analysis reveals that the literature has not identified all the reasons why a group of science majors decided to pursue science teaching. Four novel motives (those provided by participants but not described in the literature) are identified which should inform future research into science teacher recruitment.

\section{METHODS \\ Participants}

This study took place in the College of Education (COE) at a public research university of approximately 40,000 students located within the greater metropolitan area of a major US city (referred to hereafter as "the University"). I used purposive sampling to identify the students in 
an introductory science teaching methods course who planned to apply to the University's secondary science teaching program. At the University, this course satisfies a general education requirement and does not require students to have shown prior interest in or commitment to teaching. Not all students enrolled in the course go on to pursue science teaching, and those who do may opt to apply to programs in either secondary science or middle school math and science. In the semester this study was conducted, fourteen of the twenty-four students in the course planned to pursue science teaching at the University. All seven students who indicated an intention to apply to the secondary science program consented to participate in this project, however, one student did not reply to requests to schedule an interview. Self-reported background information for the remaining six participants is summarized in Table 1 (pseudonyms have been used).

\section{Data Collection}

To learn more about why undergraduate science majors decide to enter a science teacher preparation program, I interviewed participants following the completion of their introductory science teaching methods course. I conducted interviews using a semi-structured interview protocol containing 30 to 40 items that were individualized to each participant based on their responses to an 18-item online pre-interview survey. Both the online survey and the interview protocols were informed by the literature on pre-service science teacher recruitment. Interviews were audio recorded. No notes or artifacts were collected from the interviews, although I wrote analytic memos following the conclusion of each interview. I used InqScribe digital media transcription software to transcribe audio-recordings of the interviews.

\section{Literature Review}

I conducted an exhaustive review of the literature on secondary science education recruitment utilizing Creswell's (2002) five-step approach. The literature review yielded both studies describing how career interests in science teaching form and studies offering recommendations for recruiting science majors into initial science teacher certification programs. The results of these studies served as a source of deductive codes.

\section{Data Analysis}

To determine whether the current literature on science teacher recruitment has captured all the reasons why a group of prospective pre-service science teachers

Table 1. Self-reported background information

\begin{tabular}{|c|c|c|c|c|}
\hline & Science major & $\begin{array}{l}\text { Racial/ethnic } \\
\text { background }\end{array}$ & Academic year & Education program applied to \\
\hline Eric & Biology & $\begin{array}{l}\text { White \& Native } \\
\text { American }\end{array}$ & $3^{\text {rd }}$ year/Junior & $\begin{array}{l}\text { Five-year integrated master's degree } \\
\text { with certification }\end{array}$ \\
\hline Bryan & Biology & White & $3^{\text {rd }}$ year/Junior & $\begin{array}{l}\text { Four-year double major in science and second- } \\
\text { ary science education with certification }\end{array}$ \\
\hline Sarah & Biology & Indian & $3^{\text {rd }}$ year/Junior & $\begin{array}{l}\text { Four-year double major in science and second- } \\
\text { ary science education with certification }\end{array}$ \\
\hline James & Chemistry & Asian-American & $3^{\text {rd }}$ year/Junior & $\begin{array}{l}\text { Four-year double major in science and second- } \\
\text { ary science education with certification }\end{array}$ \\
\hline Tom & Biology & White & $4^{\text {th }}$ year/Junior & $\begin{array}{c}\text { Five-year integrated master's degree with } \\
\text { certification }\end{array}$ \\
\hline
\end{tabular}


decided upon a career in science education, it was necessary to develop a rich understanding of why each student decided to pursue science teaching. I determined that this goal would be best accomplished via a qualitative research methodology. I chose to construct a multi-case study using a directed qualitative content analysis approach. In this analysis, each participant's experiences in and reasons for choosing to pursue science teaching represent a unique case, as I expected no two participants to have followed the same pathway from science major to prospective science educator. Multiple cases were used to increase the likelihood that I would identify novel motives for pursuing science teaching, and to evaluate the degree to which individual students' pathways were or were not similar.

Qualitative content analysis can be defined as "a research method for the subjective interpretation of the content of text data through the systematic classification process of coding and identifying themes or patterns" (Hsieh \& Shannon, 2005). As a research method, one of its primary affordances is flexibility, as analysis may be conducted via an inductive or deductive approach (Elo \& Kyngäs, 2008). Further, it can be used to describe both novel or uncharacterized phenomena and incompletely analyzed or characterized phenomena. I chose qualitative content analysis due to this flexibility, as I knew the use of both inductive and deductive coding would be necessary to answer my research question. I consider this qualitative content analysis to be directed (Hsieh \& Shannon, 2005) because it was informed by existing, potentially incomplete research findings regarding science teacher recruitment.

To accomplish my goal of identifying novel motives for pursuing science teaching, two rounds of coding were done. In the first round, I coded all transcripts inductively, using an open coding method. Portions of the transcripts dealing with (1) what factors impacted participants' interest in science teaching, and (2) participants' knowledge of or experience with recruitment strategies were highlighted and given descriptive codes. I then reviewed these descriptive codes and collapsed similar codes into categories. To assess the reliability of the inductive coding scheme and minimize subjectivity, my process of category development was responsive to criticism and feedback. During the year I spent transcribing, coding, and analyzing interview data from this study, I participated in a weekly research seminar with fellow science education graduate students and faculty. At these meetings, I shared my inductive coding scheme and subsequent emerging categories along with supporting evidence from participant interview transcripts. My categories were refined and modified in response to feedback from my colleagues. Using this method, I ensured that my inductive coding scheme was both transparent and systematic, characteristics identified as essential for rigorous qualitative research (Meyrick, 2006).

A second round of coding utilized deductive coding. I selected deductive codes after conducting a review of the literature on recruiting science majors into secondary science teaching programs (see Table 2). To minimize potential researcher bias and reduce coding errors, the reliability of the deductive coding scheme was assessed using two pilot interviews. Three pages of interview transcript, comprising greater than 10 percent of the total pilot transcript data (Campbell, Quincy, Osserman, \& Pedersen, 2013; Hodson, 1999) were reviewed and coded by myself and two other graduate assistants. There was greater than 90 percent agreement between each pair of coders, demonstrating high intercoder reliability (Neuendorf, 2016); further, through negotiated agreement (Campbell et al., 2013), we were able to resolve the discrepancies between our coding, ensuring a high degree of both intercoder reliability and agreement.

I reviewed coded transcripts and used them to construct a case for each participant. Those cases are presented as narrative profiles in the next section. Profiles were constructed with a focus on the factors that impacted participants' interest in science teaching and participants' knowledge of or experience with recruitment strategies.

To determine whether the literature has adequately identified all the reasons why participants decided to pursue science teaching, I compared categories arising from open coding to the deductive codes generated from the literature. Any open coding categories that lacked a homologous deductive code represented a novel motive for the pursuit of science teaching. Further, any deductive code not found in the transcripts represented a previously identified motive that did not play a role in these participants' career decisions. Any discrepancies between the literature and the experiences of the six participants are summarized in the Discussion section.

\section{RESULTS}

\section{Eric}

Eric's interest in teaching developed in high school. He considered teaching English or science, as those were his favorite subjects. Eric explained that teaching interested him because:

I've just seen really good teachers and apathetic teachers, and just realizing the potential, of having a positive influence on people, that's what really motivated me to want to become a teacher... seeing the different types of teachers, that made me really want to be a teacher. 
Table 2. Deductive codes derived from the literature

\begin{tabular}{|c|c|c|}
\hline Coding category & Specific code & Reference \\
\hline \multirow{13}{*}{$\begin{array}{l}\text { Reasons science } \\
\text { undergraduates } \\
\text { consider science } \\
\text { teaching }\end{array}$} & 1. Affinity for science & $\begin{array}{l}\text { Bull et al., 1994; Dawson, 2007; Dominguez et al., 2015; Eick, } \\
\text { 2002; Espinet et al., 1992; Kilinç \& Seymen, } 2014\end{array}$ \\
\hline & 2. Positive social impact & $\begin{array}{l}\text { Bull et al., 1994; Dawson, 2007;Dominguez et al., 2015; } \\
\text { Eick, 2002; Kilinç \& Seymen, } 2014\end{array}$ \\
\hline & 3. To work with youth & $\begin{array}{l}\text { Bull et al., 1994; Dawson, 2007; Espinet et al., 1992; Kilinç \& } \\
\text { Seymen, 2014,Westerlund et al., } 2011\end{array}$ \\
\hline & 4. Positive prior teaching experience & $\begin{array}{l}\text { Dawson, 2007; Kilinç \& Seymen, 2014; Luftet al., 2005; Wang, } \\
2004\end{array}$ \\
\hline & $\begin{array}{l}\text { 5. Positive impact by a former } \\
\text { teacher }\end{array}$ & Dawson, 2007; Tomanek \& Cummings, 2000 \\
\hline & $\begin{array}{l}\text { 6. Valuing the teaching } \\
\text { profession }\end{array}$ & $\begin{array}{l}\text { Dawson, 2007; Dominguez et al., 2015; Espinet et al., 1992; } \\
\text { Kilinç\& Seymen, } 2014\end{array}$ \\
\hline & $\begin{array}{l}\text { 7. Opportunity to engage with } \\
\text { science }\end{array}$ & Eick, 2002; Tomanek \& Cummings, 2000 \\
\hline & $\begin{array}{l}\text { 8. Job conditions (i.e. } \\
\text { salary, demand, \& work- } \\
\text { load) }\end{array}$ & $\begin{array}{l}\text { Dawson, 2007; Dominguez et al., 2015; Kilinç\& Seymen, 2014; } \\
\text { Wang, } 2004\end{array}$ \\
\hline & 9. Recruitment & \\
\hline & $\begin{array}{l}\text { a. Science teaching } \\
\text { experiences }\end{array}$ & $\begin{array}{l}\text { Borgerding, 2015; Saxman et al., 2010; Schuster, 2013; } \\
\text { Tomanek\& Cummings, 2000; Worsham et al., } 2013\end{array}$ \\
\hline & b. Financial incentives & Liou et al., 2010 \\
\hline & c. Introduction to & Hoff \& Lee, 1986 \\
\hline & $\begin{array}{l}\text { science teaching careers } \\
\text { course }\end{array}$ & \\
\hline \multirow{5}{*}{$\begin{array}{l}\text { Reasons science } \\
\text { undergraduates } \\
\text { do not consider } \\
\text { science teaching }\end{array}$} & 10. Low salary & Evans, 1987; Worsham et al., 2013 \\
\hline & 11. Classroom management concerns & Evans, 1987; Worsham et al., 2013 \\
\hline & $\begin{array}{l}\text { 12. Discouragement from family \& } \\
\text { friends }\end{array}$ & Evans, 1987 \\
\hline & $\begin{array}{l}\text { 13. Difficulty incorporating teacher } \\
\text { preparation into current plan of } \\
\text { study }\end{array}$ & Worsham et al., 2013 \\
\hline & 14. High achievement in science & Moin et al., 2005; Shugart \&Hounshell, 1995 \\
\hline
\end{tabular}

He chose science teaching over English teaching because of a combination of his interest and ability in science, explaining, "I really like science and I like to visualize it, and I feel like it's a good way to learn it, so I feel like I would be a decent science teacher." In high school, Eric also considered a career in science research, which led him to apply to the University as a biology major. His mother encouraged this interest by helping him get a summer research internship at the FDA, where she works as a researcher. This internship, which took place in the summer between high school and college, convinced Eric that research was not for him. He shared that "from day 
one [of college] I knew that I was going to be an education major. So I attended the first change of major workshop that I could to get into education."

Since entering college, Eric's decision to pursue science teaching has been affirmed by several experiences. He has worked as a teaching assistant, which has given him practice in planning and differentiating lessons to different types of students. He has worked with elementary and secondary students through volunteer opportunities and as a Noyce scholar, and has realized that he has an affinity for young people, stating that "I just feel more free to be myself in front of kids than adults." Teaching experiences from the Noyce program have also given Eric "the opportunity to see if this is what I'm meant to do, and it was. It was very affirming". Eric has also recognized a disconnect between himself and the pre-med students who dominate the biology major:

I came into it [college] thinking I was a science education person. I don't really like the types of people who are science pre-meds, because they're stuck up in their life, their future life, and the monotony that it is. And they're very focused on being successful. I, too, would like to be successful, but it's a different type of thing. The education type of people, the humanities type of people are more open-minded and empathetic... they're [biology majors] going for grad school and medical school and it's very competitive.

The value given to empathy in education is important for Eric, who shared that, "I like helping people more than I like helping myself. It makes me happy." Eric was unaware of any recruiting efforts being made by the COE aside from the Robert Noyce Teacher Scholarship Program, a nationwide, National Science Foundation funded program in which the University participates that provides scholarships to science majors pursuing science education. While Eric is a Noyce scholar, he joined the program after deciding to teach, so it did not impact his choice to pursue teaching.

Eric has been discouraged from pursuing teaching by his friends because of teachers' income potential. While Eric identified salary as a negative of teaching, he was unconcerned because teaching is "fulfilling and rewarding in ways besides money." Eric was critical of the advising he has received from the COE, and has had difficulty in getting correct information about which courses are required for the teacher preparation program. He says he has only been able to "figure it out through repeatedly going to advising", and says that friends have shared similar frustrations.

\section{Bryan}

Bryan first considered science teaching during his freshman year at the University. In high school, he considered a career in either science or history, as those were his two favorite subjects. He explains:

What made me decide that I wanted to go into science, because I really like history, too, was the job market. I knew that in history you don't really get a job, you know, science is highly needed with STEM and stuff like that.

When he entered college, he planned to become a doctor, but shared that he began questioning this decision because:

I started realizing that I don't think I wanted to spend my 20's in school, or go to the route where I would not be able to work with people other than having patients, because I really like working with people, especially younger people.

Bryan was given a work-study position in the COE during his freshman year. While he believes that he would have eventually come to teaching without this position, he acknowledges that it did have an influence on his decision, as it came during a time when he "was starting to think about other options." Bryan decided to become a science teacher by the beginning of his sophomore year.

Bryan recognizes that his decision to become a teacher was influenced by prior teaching experiences. His first "practice in teaching" came from tutoring in chemistry and physics during high school. In college, he gained more experience teaching lifeguarding classes, which included science concepts such as the "cardiac cycle", and realized that he "really enjoyed standing up in front of people and teaching... I started liking the idea of instead of being selfish with my knowledge, being able to provide it to everyone else, too." Bryan's decision was also motivated by the possibility of impacting the quality of science education in rural areas; he felt that his rural science education left him ill-prepared for the rigors of college science courses, although he did acknowledge that his best teacher was his high school chemistry teacher. He believes that "the best way to fight back against a system that might be going bad is to get in it and do it the right way and support the right ways to teach". Bryan has received encouragement from people in his hometown, who hope that he will return to the community to teach science. Bryan also shared a desire to work with people, especially young people because, "they are so excited all the time, and it's neat to make them happy." Bryan looks forward to the job conditions of teaching, sharing:

I like how the teachers work together, and the sense of camaraderie among coworkers that you wouldn't get if you had a job where you didn't really work with other people trying to achieve the same goal. The hours are nice, the benefits are great, and if I ever wanted to have 
a family, it's perfect, too, to have summers off.

While Bryan recognizes that teachers' salary may be off-putting for many of his science major peers, especially physics and chemistry majors who "could get a six-figure salary", it was not a concern for him, because he's "not a big spender" and comes "from a family that's not rich". He did receive discouragement from his grandmother, a retired English teacher: "My grandmother doesn't really support people who want to become teachers because she thinks the system is getting bad. She's not a fan of common core and she doesn't like how it's all about tests now", but she was unable to dissuade Bryan from pursuing teaching.

\section{Sarah}

Sarah decided to become a science teacher because of her experiences during the introductory science teaching methods course. Sarah was interested in science from an early age, and first remembers deciding upon a career in science at age 13. By high school, she decided that she wanted to be a doctor, although she explains that

I'd always thought of teaching when I was in high school. I always really liked teaching, but I just never really pictured myself as being a teacher... I always liked teaching, I just never saw it as, this is what I'm going to do.

This interest may have been influenced by her high school science teachers, who were "really great teachers... they really liked the subject they were teaching, you could tell that they weren't just there to do their job." During high school, Sarah also began what has become a yearly summer internship at a biomedical research facility. Although Sarah entered the University intending to become a doctor, the influence of her summer internship experience led her to instead plan for a career in biological research.

While still intending to become a researcher, Sarah realized that she had enough free credits to earn a minor. At the same time, Sarah's interest in teaching was revived by a positive experience working as a teaching assistant. Knowing Sarah's interest in education, her sister suggested that she add a minor in education. After speaking to her advisor, Sarah decided to add a second major in secondary science education, although she still planned for a career in research. Sarah explains that:

After I decided to double major in education, I started to see it as a more realistic option, as opposed to just a backup plan. That was when I realized that I actually did enjoy the possibility of being a teacher.
Sarah decided that she wanted to work as a science teacher because of an internship in a local high school that was a requirement of the introductory science teaching methods course. Her change in career aspiration was inspired by observing teachers, which she identified as falling into two categories, those who could motivate struggling students to do better, and those who just wanted struggling students not to disrupt their class, saying that:

When I saw that, it made me want to change that and to be that teacher who pushes students to do better, to not just be like okay, just sit in the back of the class and don't disrupt people.

Sarah believes that teachers do not receive the financial compensation that they deserve, but says that "I've accepted that I'm not going to get the most fabulous pay, but I'm okay with that considering that I've chosen this, so I'm not going to complain about it." She has been discouraged from pursuing teaching by her friends and family because of the profession's salary and perceived low prestige; she shared that her father "was surprised because he felt like I could do more than just teach, like I was settling for being a teacher." While she understands their concerns, she is pushed to continue to pursue science teaching because she enjoys teaching.

\section{Alice}

Alice first considered science teaching during her sophomore year of college. Alice comes from a family that highly values science - both of her parents are scientists, and her brother is in medical school - so she always expected to work in science. She decided to become a pediatrician after taking anatomy in $11^{\text {th }}$ grade, since it would allow her to combine her interest in the human body and "working with kids." Alice's father convinced her to enter the University as a bioengineering major, but Alice struggled with the major's physics and mathematics requirements. She explained:

I decided I can't really do this engineering thing, all this physics in it is not really my thing. Math has always been hard for me. So, I decided not to do bioengineering. I decided to change to just bio.

Initially, she still intended to become a doctor, but realized that she "didn't want that stressful pre-med life anymore" and that it would be difficult for her to raise her GPA to a level competitive with her pre-med peers. At that point, Alice shared:

I think I realized, because I knew I wanted to work with 
kids and I liked working with kids, there were other ways to help people than just being a doctor who works with kids. And I was like maybe l'll try out education.

Alice ideally would have chosen elementary education, but was discouraged by her father, who said "you can't just do elementary education" and because she felt like she would be wasting all the biology credits she had already earned, so she decided to enter the secondary science program.

Alice's decision was impacted by several volunteer experiences, including tutoring, camp counselling, and an afterschool math and science program. She participated in these programs because they gave her an opportunity to work with children, but she says they also gave her "an opportunity to see what it would be like to actually teach kids in a subject area". Alice is also motivated by the possibility "to work in the urban areas and help people who have much more need than where I came from." She also identified job security as a benefit of the teaching profession, saying that "people will always need teachers." While Alice was not initially encouraged to pursue teaching by her friends and family, she said that "a lot of people now are affirming me for being in science education, a lot of them are like, oh, I can imagine you as a teacher or you'd be a great teacher."

Alice identified salary as a con of teaching, but says that "I think it discouraged my dad more than me. I'm not too worried about it." She hopes to teach in an urban area, but expressed concern over the emotional toll of ongoing classroom management issues. Although Alice's father was initially disappointed and discouraged her from pursuing science teaching, he has accepted her decision because it does not require her to abandon a degree in science, which he views as a backup plan in case she does not like teaching.

\section{James}

James never seriously entertained any career options other than science teaching. He shared:

I always sort of knew in the back of my mind that I had a gift of teaching, meaning that whenever I am teaching, or whenever I am translating information, or whenever I am just guiding someone to learn something, I'm particularly good at it compared to my peers. I always noticed that in high school, so that's when I thought of becoming a teacher.

In high school, James' parents encouraged him to explore other career options that they viewed as being more prestigious:
I don't know if you know, but traditional Asian parents, they want you to be a doctor... a lot of parents have the dream of, since I didn't do well, I want my sons and daughters to do well, so my parents had the idea of why don't you become a doctor. So, I thought of pharmacist, because it has to do with chemistry. I gave it a thought, of being a doctor.

By the start of his freshman year, James had decided to become a science teacher. He explained that the decision was the result of "a gradual acceptance" of himself and struck a balance between "all the things that I've been through, all the things that I want to do, and what I'm good at."

James' decision to pursue science teaching was inspired and facilitated by former teachers. As an English language learner, James struggled in his eighth-grade English class, but explains:

My teacher really didn't ever give up on me... that was
when I sort of defined a good teacher as a teacher who
really pays attention, who really gives attention to his
or her students. Who really likes, not only teaching, but
students. That was when I thought maybe teaching is
one thing that I really want to do, to really help those
who were in my situation, who didn't really like learning,

James developed a close friendship with his Advanced Placement chemistry teacher, who was a graduate of the University's science teacher preparation program and encouraged him to become a teacher. James also acknowledges the impact that tutoring has had on his career plans, sharing that "tutoring is actually a big part of my life"; he has tutored continually since $10^{\text {th }}$ grade. Like Eric, James is a Noyce scholar, but he also joined Noyce after committing to teach. Tutoring, education internships, and the Noyce program have served to develop and affirm his decision to teach science.

James believes that some teachers are inadequately compensated for their work, but is not discouraged by salary expectations. Although his parents were initially disappointed by his decision to become a science teacher, he shared that "now they're really supportive of my decision." He expressed some concern over classroom management issues, which may lead him to teach in a suburban, rather than urban, school district.

\section{Tom}

In high school, Tom briefly considered a career in medicine or law, but decided to become a math teacher due to his aptitude in math and desire to help people. He shared:

I always liked helping people... it is very rewarding to help people. I know what it's like to be helped, and I want to help people's lives be easier with school. I've had a lot 
of negative experiences with it, and I don't think it needs to be that negative. You can enjoy learning, and you're in school for so long you should enjoy it.

Tom entered the University intending to double major in mathematics and secondary education, but quickly realized that he "didn't want to do math anymore." A positive experience in his freshman biology course led him to switch majors to biology; he explained:

I started liking science, so I dropped education and thought about pursuing a science field, biology. I was thinking about being a nurse or a PA... I never like stopped liking teaching, but I didn't want to be a math teacher.

Tom quickly realized that he did not want to become a health professional, due to the length of school required, so he reconsidered teaching. He explained,

I found out that I like biology, it's kind of hard, but I also like teaching, and it just kind of worked out so my junior year I decided to put the two together... Teaching is an incredibly rewarding job. And it matches up with me not wanting to be in school as a student for a very long time... Teaching has always kind of been my first goal, and then biology came secondly.

Tom attributes his interest in teaching in part to his family, sharing, "my family are also all teachers or principals... they definitely never pushed me, I don't think, but I just see them as they are and I see they're happy and I see all of us doing well." Although Tom has not tutored formally, he has always helped his friends study, explaining "if they were struggling and I knew it was something I was good at, I always would jump on it before they even asked", and feels that these experiences influenced his decision to become a science teacher. He has worked with children of all ages and is drawn to working with young people because of the opportunity to create an environment where they can discover "who they are."

Tom has had difficulty incorporating the requirements of the University's science teacher preparation program into his academic plan. Since he changed his major from mathematics to biology and is now adding a second major in secondary education, he will need to stay at college for a fifth year. He also has had to defer application to the program to the spring to raise his GPA to that mandated by the program, but can continue to take required education classes in the interim.

\section{DISCUSSION}

I found that all the factors identified as positively contributing to the development of science teaching interest by the literature on science teacher recruitment played a role in some or all the participants' decisions to enter science teaching (Table 3). Consistent with the literature, all six participants expressed a strong affinity for science and viewed science teaching as a way to remain deeply engaged with science content, rather than as a means of distancing themselves from science. Also, consistent with the literature, all participants valued the teaching profession, expressing admiration and respect for the work of teachers and disdain for the current low status of teachers. All participants except Eric had gained teaching experience (although of varying formality and duration) via tutoring, teaching assistantships, and/or summer camp work prior to making the decision to pursue science teaching. All participants except James cited the opportunity to work with youth as a compelling reason to choose teaching; James shared that he did not have a specific desire to work with young people, but instead a more general desire to work with people that teaching fulfilled.

Participants expressed mixed commitments to making a positive social impact. Sarah and Alice explicitly desired to effect change in urban areas and Bryan explicitly desired to effect change in rural areas, due to perceived deficits in the quality of science instruction in those areas. While other participants did not express social change to be a priority, all participants cited a more general desire to help people as a motivating factor in their decision to pursue teaching. For example, Tom shared, "I always liked helping people... it is very rewarding to help people." Participants also differed in the role the influence of former teachers had in their decision. Sarah and James had former teachers who inspired them to pursue science teaching, either indirectly through their contagious passion for the subject (Sarah) or directly through acting as a mentor (James). Far from being inspired by their former teachers, Eric, Bryan, and Tom criticized the quality of science instruction they received as secondary science students. For Bryan, Alice, and Tom, job conditions related to teaching, such as job security, work-life balance, and schedule, were also motivating factors in their decision.

No participants felt that they had been recruited into the science teacher preparation program by the COE; in fact, only two participants recalled being aware of any efforts to recruit science majors into the program. Eric and James were Noyce Scholars, a program that is intended to encourage science and mathematics undergraduates to explore teaching; however, Eric and James both applied for the scholarship after they had already decided to pursue teaching, so they were not recruited by the scholarship, even though they recognized that to be its intended 
Table 3. Factors positively impacting science teaching interest, from literature

\begin{tabular}{|c|c|c|c|c|c|c|}
\hline & Eric & Bryan & Sarah & Alice & James & Tom \\
\hline Affinity for science & Yes & Yes & Yes & Yes & Yes & Yes \\
\hline Positive social & No & Yes & Yes & Yes & No & No \\
\hline Positive prior teachingexperience & No & Yes & Yes & Yes & Yes & Yes \\
\hline Valuing the & Yes & Yes & Yes & Yes & Yes & Yes \\
\hline \multicolumn{7}{|l|}{ teachingprofession } \\
\hline Opportunity to engage with science & Yes & Yes & Yes & Yes & Yes & Yes \\
\hline Job conditions & No & Yes & No & Yes & No & Yes \\
\hline Recruited? & No & No & No & No & No & No \\
\hline
\end{tabular}

purpose. All participants initiated their relationships with the COE; in some cases, this required perseverance, as some participants expressed frustration over their difficulty in obtaining reliable information about the program through advisors and the COE's website.

Even though my participants included only science majors who planned to pursue science teaching, I was interested to see if they shared any of the concerns of science majors who choose not to become science teachers that have been reported in the literature (Table 4). None of the six participants were concerned with science teacher salary expectations. While all participants identified pay as a con of the teaching profession, they were not personally concerned with their ability to live with a teacher's salary. Both female participants shared that low pay was particularly concerning to their parents, who encouraged them to pursue more lucrative career paths. This parental concern was not shared by any of the male participants. Only Alice and James expressed concern over classroom management, and their concern was limited to urban classroom contexts. Tom was the only participant who was not discouraged from pursuing science teaching by his family, friends, or science classmates. Alice and James attributed their family's discouragement, in part, to their Asian-American backgrounds, claiming that in their families, teaching is not held to the same esteem as other science professions. Sarah discussed her father's reaction to her decision to teach, sharing that he was "kind of surprised because he felt that I could do more than just teach, it was like I was settling for being a teacher." Only Tom had difficulty incorporating teacher preparation requirements into his course of study, and this was due more to his earlier major change than to the demands of the education dual major. Contrary to findings by Moin et al. (2005), all six participants had GPA's of at least 3.0 (this is a pre-requisite for application to the University's science teaching program). The existing literature on science teacher recruitment has captured many of this group of undergraduate science majors' reasons for pursuing science teaching; however, the following motivations were not reported in the literature.

\section{Influence of Negative Examples}

While the literature has identified the positive impact of previous teachers as a factor that motivates interest in 
Table 4. Factors negatively impacting science teaching interest, from literature

\begin{tabular}{|c|c|c|c|c|c|c|}
\hline & Eric & Bryan & Sarah & Alice & James & Tom \\
\hline Low salary & No & No & No & No & No & No \\
\hline Classroom managementconcerns & No & No & No & Yes & Yes & No \\
\hline Discouragement from family \& friends & Yes & Yes & Yes & Yes & Yes & No \\
\hline Difficulty incorporating teacher prep & No & No & No & No & No & Yes \\
\hline $\begin{array}{l}\text { High achievement in science (GPA } \geq 3.0 \text {, } \\
\text { Moin et al., 2005) }\end{array}$ & Yes & Yes & Yes & Yes & Yes & Yes* \\
\hline
\end{tabular}

*Tom's GPA would be 3.0 at the time of application to the program

science teaching, Eric, James, and Tom's decisions to enter science teaching were motivated by negative experiences with teachers. Eric contrasted his English teacher, who "obviously didn't put in any work, didn't care to expand our knowledge... didn't go above and beyond the bare minimum" with his math teacher, who "was very good at explaining things and encouraging me... he expected success out of me", and explained:

I've just seen really good teachers and apathetic teachers, and just realizing the potential, of having a positive influence on people, that's what really motivated me to want to become a teacher... seeing the different types of teachers, that made me really want to be a teacher.

James described how his chemistry teacher, "who didn't really teach me effectively", inspired him to consider teaching:

[I thought] maybe if I became a teacher who actually teaches things and relates materials to real life situations, maybe I want to do that I realized. I think that was a moment when I sort of thought of becoming a teacher.

Tom explained that his science teachers demonstrated "more what not to do than what to do" as a teacher. These negative experiences influenced Tom to choose science teaching so that he could create positive learning experiences for his students.

\section{Desire to Enter Workforce Quickly}

The decisions of Bryan, Sarah, Alice, James, and Tom to enter science teaching were all motivated by a desire to begin a career quickly, rather than spend years in graduate or professional school, which they considered to be necessary for a career in science. Many also felt that this represented a disconnect between themselves and their science major peers, who they felt were looking forward to spending a long time in school. Bryan shared that most science majors:

Seem to be dead set dedicated on spending a really long amount of time in school to become a doctor or what not. And I started realizing that I don't think I want to spend my twenties in school... I like the idea of being able to finish my undergrad and have a job, so I'll be honest with that part.

Tom shared similar priorities as he explained his decision to pursue teaching instead of a career in the medical profession:

I'm trying to be done with school as quickly as possible, even if my grades were as high as they need to be for being a doctor, I definitely do not want to be pursuing that, I'm not interested in being in school that long... I didn't want to put in the time in school to get there. I was ready to move on as quickly as possible to being an independent person.

Since the University's science teacher preparation program can be completed alongside a science major within four years, a career in science teaching fulfilled the desire to being in the workforce as soon as possible. 


\section{Identity}

Participants' decisions to pursue science teaching were the result of a process of self-discovery that consisted of (1) acknowledging their own interests, strengths, and values, or identity, and (2) recognizing that that identity makes them better suited for a career in science teaching than for other careers they considered. Participants progressed through this process at different rates, which is why they made the decision to teach science at different points in their education. I believe that positive prior teaching experience contributes so strongly to an interest in science teaching because it facilitates this process of self-discovery. This process is described by James:

It was a gradual acceptance of myself as, I keep saying gifted, but l'm not saying that to promote myself in another way, but I'm just saying that I was just innately able to deliver information and make things more interesting than my peers and others, and an average person. So, I think that knowing about myself and having that just conscience of myself was one of the factors that really got me into teaching science, that was one of the factors. And all of these experiences I had up until now, internships, even volunteering work, these really were all the factors that got me into, that got me more into teaching because obviously the experiences I had were after I had made the decision to teach, of becoming a teacher. But, I guess it wasn't a decision that I wanted to become a teacher, but maybe I should try out becoming a teacher and then as I was having these experiences, I was able to confirm myself and confirm my decision.

Some participants recognized that their identity made them better suited for a career in science teaching than for other science careers after realizing that their identity was not the same as, and was sometimes in direct conflict with, that of other science majors. With the exception of James, all participants were biology majors and were critical of their science major peers. These participants felt that their peers, who were primarily pre-med students, dictated the culture of the University's College of Computer, Mathematical, and Natural Sciences (CMNS), which they characterized as one of competition and stress. Bryan explained that starting college "was a bit of a shock, I was now a small fish in a big pond... the competition was really intense." Sarah explained that "it can be hard as a science student, because there's a lot more stress coming from the exams and just the competition that there is in the science field". Alice directly attributed her change in career plans to this culture, explaining that she "didn't want that stressful pre-med life anymore." Eric compared pre-med students to students in the COE:

I don't really like the types of people who are science pre-meds, because they're stuck up in their life, their future life, and the monotony that it is. And they're very focused on being successful. I, too, would like to be successful, but it's a different type of thing. The education type of people, the humanities type of people are more open-minded and empathetic.

The mismatch between participants' identities and those of other biology majors led participants to feel out of place and seek a career option that allowed them to combine their affinity for science with their desire for cooperation and helping others. Science teaching met that need and provided a caring community of faculty and peers with similar interests, strengths, and values. This is consistent with Luehmann's (2007) identity development framework, where she contends that "people approach learning situations with core identities in place that need to align with the new identity being considered" (p. 828). Participants' core identities did not align with a science identity as presented by the CMNS, but instead with the science teacher identity common in the COE. Further, the sense of community they found in the COE ensured that their science teacher identities were recognized and validated, which Luehmann considers an essential component of science teacher identity development.

\section{Sense of Community}

All participants were critical of their experiences with professors in the CMNS at the University. Eric described his science professors:

The instructors aren't as student focused, I would say. I think it's just more getting the content out in a timely manner. They aren't focused on the ease of student comprehension, that's not their problem, the students need to work on it. They're only worried about getting what the students need to know out.

Tom was less forgiving in describing science professors, saying:

They're not very good. They read the PowerPoint for 50 minutes, give you reading assignments, and it's pretty much all on you... I don't really have a lot of good things to say about the science classes here.

James excused the quality of instruction in his science classes, because "college instructors aren't really required to have any interest or gift or anything that has to do with teaching." Alice described her science professors as "boring" and "distant", a sentiment shared by Bryan, who shared that his science classes were "too big to interact with your professors."

In contrast, participants praised the instruction they received in the COE. Sarah directly compared her 
experiences in the CMNS and COE:

It almost feels like you're in different colleges when you're in different classes for education versus bio... as an education student, you have a one on one relationship with the teacher, so it feels a lot more like you're being guided through it.

Similarly, Alice shared: "I feel like teachers who teach about teaching are good at it... that's definitely been a nice change from my normal science classes." Bryan also compared his experiences, saying "the education classes I've had, I loved way more than my science classes... the atmosphere in the classes is just really positive", and saying that he has received "intense encouragement" from the COE. Eric explained that his experience in the COE has "made me spoiled with good teachers that I feel care about my opinion. That's what I really appreciate about my education classes, the individualized sort of thing." Sarah echoed this, saying that her experience in the COE has "felt a lot more personalized."

I believe that what participants are describing in their interactions with the COE is a sense of community. Sarason (1974) defines sense of community as "the sense that one was part of a readily available, mutually supportive network of relationships upon which one could depend and as a result of which one did not experience sustained feelings of loneliness", and asserted that community is "one of the major bases for self-definition" (p. 157). Participants did not feel a sense of community in the CMNS. For participants who decided to become science teachers before college, this lack of community affirmed their self-definition, or identity, as future science teachers. For participants who decided to become science teachers during college, this lack of community motivated them to explore other career options, which brought them to the COE. Once in the COE, these participants found a sense of community, which facilitated the development of their identities as future science teachers.

\section{CONCLUSIONS}

To increase the number of recruits into initial science teacher preparation programs, schools of education must have access to research that explicates successful strategies for identifying and recruiting science majors. I conducted this analysis to evaluate claims made by Allen (2005), Luft et al. (2011), and others that the literature on the recruitment of science majors into science teaching is sparse, and unable to adequately explain why undergraduates decide to pursue science teaching. Six undergraduate science majors who have committed to an initial science teacher preparation program were interviewed to ascertain their motivations for choosing a career in teaching. I have found that while some of their reasons for becoming science teachers have been discussed in the literature on science teacher recruitment, several of their motivations have not yet been described. In addition to commonly cited factors (i.e., an affinity for science, desire to make a positive social impact, etc.), these six science majors were also influenced to teach by the professions' alignment to their identities and values, the sense of community fostered by the COE, a desire to enter the workforce quickly and the negative example of prior teachers.

The failure of the literature to capture the full range of reasons why science majors decide to enter science teaching can be attributed to several factors. First, existing studies have failed to incorporate diverse theoretical perspectives. Several studies have used career theories; however, most studies of initial science teacher recruitment are grounded in no theoretical perspective. Based on the findings of this analysis, future studies should draw upon identity and community psychology theories. Second, diverse methodologies and data sources are also needed. Many studies of teacher recruitment rely upon the use of survey instruments. While surveys can be useful, they are generally informed by previous research, and therefore have limited utility in identifying previously uncharacterized motivations, especially when the existing research they are based upon has been criticized as being sparse. Further, the use of survey instruments results in a list of isolated factors and does not allow researchers to identify the connections between these factors or to provide deeper, richer descriptions of how these factors play into undergraduates' decisions. Finally, if the goal of science teacher preparation programs is not just to increase the number of science teachers, but also the diversity of the corps of science teachers, then future studies designed to inform recruitment should include participants from diverse backgrounds. Most studies reviewed were primarily of white, female pre- and in-service science teachers; it is possible that the six undergraduates included in this study shared novel motives because they represent a more racially and ethnically diverse sample.

A limitation of this study is that it was conducted at a single university; therefore, findings may not be generalizable to students recruited into other teacher preparation programs. Similarly, the study focused on an undergraduate initial teacher certification program, so findings will not be generalizable to post-baccalaureate and/or alternate certification programs. Another potential limitation is the sample of undergraduate science majors interviewed, as they were ethnically diverse and mostly male, which is uncharacteristic of typical pre-service science teacher cohorts. As teaching assistant of the introductory 
science teaching methods course, my relationship to the participants may represent another limitation. Even though interviews were conducted after the conclusion of the course, it is possible that my affiliation with the University's College of Education impacted the candor of their responses. However, it is equally likely that my prior relationship with the participants encouraged them to reveal more about their backgrounds than they otherwise would have.

\section{REFERENCES}

Allen, M. B. (2005). Eight questions on teacher recruitment and retention: What does the research say? Denver, CO: Education Commission of the States. Retrieved from: https://files. eric.ed.gov/fulltext/ED489332.pdf

Borgerding, L. A. (2015). Recruitment of early STEM majors into possible secondary science teaching careers: The role of science education summer internships. International Journal of Environmental and Science Education, 10(2), 247-270.

Bull, K. S., Marks, S., \& Salyer, B. K. (1994). Future teacher scholarship programs for science education: Rationale for teaching in perceived high-need areas. Journal of Science Education and Technology, 3(1), 71-76. https://doi.org/10.1007/ BF01575818

Campbell, J. L., Quincy, C., Osserman, J., \& Pedersen, O. K. (2013). Coding in-depth semistructured interviews: Problems of unitization and intercoder reliability and agreement. Sociological Methods \& Research, 42(3), 294-320. https://doi.org/10.1177/0049124113500475

Council for the Accreditation of Educator Preparation (2013). CAEP 2013 standards for accreditation of educator preparation. Washington, DC. Retrieved from: http://caepnet.org/ standards/standards/

Creswell, J. W. (2002). Educational research: Planning, conducting, and evaluating quantitative and qualitative research. Upper Saddle River, NJ: Merrill Prentice Hall.

Cross, F. (2017). Teacher shortage areas: Nationwide listing, 1990-1991 through 2017-2018. Office of Postsecondary Eduation, U.S. Department of Education, Washington, DC. Retrieved from https://www2.ed.gov/about/offices/list/ope/ pol/ateachershortageareasreport2017-18.pdf

Dawson, V. (2007). Factors influencing pre-service teachers' decisions to become secondary science and mathematics teachers. Teaching Science: The Journal of the Australian Science Teachers Association, 53(4), 28-31.

Dominguez, C. R. C., Viviani, L. M., Cazetta, V., Guridi, V. M., Faht, E. C., Pioker, F. C., \& Cubero, J. (2015). Professional choices and teacher identities in the science teacher education program at EACH/USP. Cultural Studies of Science Education, 10(4):1189-1218. https://doi.org/10.1007/s11422-014-9650-8

Eick, C. J. (2002). Studying career science teachers' personal histories: A methodology for understanding intrinsic reasons for career choice and retention. Research in Science Education, 32(3), 353-372. https://doi. org/10.1023/A:1020866111670

Elo, S., \& Kyngäs, H. (2008). The qualitative content analysis process. Journal of Advanced Nursing, 62(1), 107-115. https:// doi.org/10.1111/j.1365-2648.2007.04569.x
Espinet, M., Simmons, P. E., \& Atwater, M. A. (1992). Career decisions of K-12 science teachers: Factors influencing their decisions and perceptions toward science teaching. School Science and Mathematics, 92(2), 84-91.

Evans, R. H. (1987). Factors which deter potential science/ math teachers from teaching; changes necessary to ameliorate their concerns. Journal of Research in Science Teaching, 24(1), 77-85. https://doi.org/10.1002/tea.3660240108

Hodson, R. (1999). Analyzing documentary accounts (No. 128). Sage.

Hoff, D., \& Lee, C. (1986). Exploring science teaching as a career. Journal of College Science Teaching, 15, 457.

Hsieh, H. F., \& Shannon, S. E. (2005). Three approaches to qualitative content analysis. Qualitative Health Research, 15(9), 1277-1288. https://doi.org/10.1177/1049732305276687

Ingersoll, R. M., \& May, H. (2012). The magnitude, destinations, and determinants of mathematics and science teacher turnover. Educational Evaluation and Policy Analysis, 34(4), 435-464. https://doi.org/10.3102/0162373712454326

Kahle, J. B., \& Kronebusch, M. (2003). Science teacher education: From a fractured system to a seamless continuum. Review of Policy Research, 20(4), 585-602. https://doi. org/10.1046/j.1541-1338.2003.00040.x

Kilinç A., \& Seymen, H. (2014). Preservice teachers' motivations for choosing science teaching as a career and their epistemological beliefs: Is there a relationship? Journal of Turkish Science Education, 11(1), 115-132.

Liou, P. Y., Kirchhoff, A., \& Lawrenz, F. (2010). Perceived effects of scholarships on STEM majors' commitment to teaching in high need schools. Journal of Science Teacher Education, 21(4), 451-470.

Luehmann, A. L. (2007). Identity development as a lens to science teacher preparation. Science Education, 91(5), 822-839. https://doi.org/10.1002/sce.20209

Luft, J. A., Wong, S. S., \& Semken, S. (2011). Rethinking recruitment: The comprehensive and strategic recruitment of secondary science teachers. Journal of Science Teacher Education, 22(5), 459-474. https://doi.org/10.1007/s10972-0119243-2

Meyrick, J. (2006). What is good qualitative research? A first step towards a comprehensive approach to judging rigour/ quality. Journal of Health Psychology, 11(5), 799-808. https:// doi.org/10.1177/1359105306066643

Moin, L. J., Dorfield, J. K., \& Schunn, C. D. (2005). Where can we find future K-12 science and math teachers? A search by academic year, discipline, and academic performance level. Science Education, 89, 980-1006. https://doi.org/10.1002/ sce. 20088

Neuendorf, K. A. (2016). The content analysis guidebook. Sage.

Sarason, S. B. (1974). The psychological sense of community: Prospects for a community psychology. Jossey-Bass.

Saxman, L. J., Gupta, P., \& Steinberg, R. N. (2010). CLUSTER: University-science center partnership for science teacher preparation. New Educator, 6, 280-296. https://doi.org/10.1 080/1547688X.2010.10399606

Schuster, D. (2013). In pursuit of sustainable STEM certification programs. Journal of College Science Teaching, 42(4), 38-45. Shugart, S. S., \& Hounshell, P. B. (1995). Subject matter competence and the recruitment and retention of secondary science teachers. Journal of Research in Science Teach- 
ing, 32(1), 63-70.

Sutcher, L., Darling-Hammond, L., \& Carver-Thomas, D. (2016). A coming crisis in teaching? Teacher supply, demand, and shortages in the US. Learning Policy Institute.

Tomanek, D., \& Cummings, K. E. (2000). The use of secondary science classroom teaching assistant experiences to recruit academically talented science majors into teaching. Science Education, 84(2), 212-227. https://doi.org/10.1002/ (SICI)1098-237X(200003)84:2<212::AID-SCE5>3.0.CO;2-P

Wang,H.H.(2004). Whyteachscience?Graduatesciencestudents' perceived motivations for choosing teaching as a career in Taiwan. International Journal of Science Education, 26(1), 113-128. https://doi.org/10.1080/0950069032000070243

Westerlund, Julie F., Radcliffe, Rich, A., Smith, Daniel A., Lemke, Maureen R., \& West, S. S. (2011). Profiles of U.S. science teacher candidates: Safeguards amidst the gathering storm. International Journal of Environmental and Science Education, 6(3), 213-227.

Wilson, S. M., Bell, C., Galosy, J. A., \& Shouse, A. W. (2004). "Them that's got shall get": Understanding teacher recruitment, induction, and retention. Yearbook of the National Society for the Study of Education, 103(1), 145-179. https://doi. org/10.1111/j.1744-7984.2004.tb00033.x

Worsham, H. M., Friedrichsen, P., Soucie, M., Barnett, E., \& Akiba, M. (2013). Recruiting science majors into secondary science teaching: Paid internships in informal science settings. Journal of Science Teacher Education, 25(1), 53-77. https:// doi.org/10.1007/s10972-013-9360-1 